\title{
Pengaruh Motivasi Berwirausaha dan Pengetahuan Kewirausahaan Terhadap Keberhasilan Usaha Bisnis Farmasi Di Kecamatan Medan Petisah
}

\author{
*Pesta Gultom" ${ }^{1}$ Liza Agustine \\ Program Studi Manajemen, STIE Eka Prasetya, Indonesia \\ 1pesta65.gultom@gmail.com \\ ${ }^{2}$ lizaa389@gmail.com
}

\begin{abstract}
This study aims to determine the effect of Entrepreneurial Motivation on Bussiness Success at Pharmaceutical Business in Medan Petisah District, determine the effect of Entrepreneurship Knowledge on Bussiness Success at Pharmaceutical Business in Medan Petisah District, determine the effect of Entrepreneurial Motivation and Entrepreneurship Knowledge on Bussiness Success at Pharmaceutical Business in Medan Petisah District. The population in this study are owners of Pharmaceutical Business in Medan Petisah District totaling 40 respondents. The technique of determining the number of samples used in this study is saturated sample and totaling 40 respondents.. The results of the research analysis show that Entrepreneurial Motivation and Entrepreneurship Knowledge partially have a positive and significant effect on Bussiness Success at Pharmaceutical Business in Medan Petisah District. The results showed that Entrepreneurial Motivation and Entrepreneurship Knowledge simultaneously have a positive and significant effect on Bussiness Success at Pharmaceutical Business in Medan Petisah District. The results of this study are supported by the value of $R$ square $\left(R^{2}\right)$ which means Entrepreneurial Motivation and Entrepreneurship Knowledge have an effect on Bussiness Success at Pharmaceutical Business in Medan Petisah District. While the remaining is effected by other factors originating from outside this research model such as business ability and entrepreneurial characteristics.
\end{abstract}

Keyword :Entrepreneurial Motivation ; Entrepreneurship Knowledge ; Bussiness Success

\begin{abstract}
ABSTRAK
Penelitian ini bertujuan untuk mengetahui pengaruh Motivasi Berwirausaha terhadap Keberhasilan Usaha pada Bisnis Farmasi di Kecamatan Medan Petisah, mengetahui pengaruh Pengetahuan Kewirausahaan terhadap Keberhasilan Usaha pada Bisnis Farmasi di Kecamatan Medan Petisah, mengetahui pengaruh Motivasi Berwirausaha dan Pengetahuan Kewirausahaan terhadap Keberhasilan Usaha pada Bisnis Farmasi di Kecamatan Medan Petisah. Populasi dalam penelitian ini adalah pemilik dari Bisnis Farmasi di Kecamatan Medan Petisah sebanyak 40 responden. Teknik penentuan jumlah sampel yang digunakan dalam penelitian ini adalah sampel jenuh dan berjumlah sebanyak 40 responden. Hasil penelitian menunjukkan Motivasi Berwirausaha dan Pengetahuan Kewirausahaan secara parsial berpengaruh positif dan signifikan terhadap Keberhasilan Usaha pada Bisnis Farmasi di Kecamatan Medan Petisah. Hasil penelitian menunjukkan Motivasi Berwirausahadan Pengetahuan Kewirausahaan secara simultan berpengaruh positif dan signifikan terhadap Keberhasilan Usaha pada Bisnis Farmasi di Kecamatan Medan Petisah. Hasil penelitian ini didukung oleh nilai $R$ square $\left(\mathrm{R}^{2}\right)$ yang artinya bahwa Motivasi Berwirausaha dan Pengetahuan Kewirausahaan mempunyai pengaruh terhadap Keberhasilan Usaha. Sedangkan sisanya dipengaruhi oleh faktor lain yang berasal dari luar model penelitian ini seperti kemampuan usaha dan karakteristik kewirausahaan.
\end{abstract}




\section{Kata Kunci: Motivasi Berwirausaha ; Pengetahuan Kewirausahaan ; Keberhasilan Usaha}

\section{PENDAHULUAN}

Seiring dengan perkembangan zaman ditandai dengan pertumbuhan ekonomi, kebutuhan hidup manusia semakin beragam. Manusia sebagai makhluk ekonomi memiliki naluri dalam memenuhi kebutuhannya untuk bertahan hidup dan selalu berambisi sehingga mendorong semakin berkembangnya pula ilmu pengetahuan dan teknologi sebagai alat atau media untuk memenuhi kebutuhan hidupnya. Hal ini mendorong peningkatan usaha bisnis di kalangan masyarakat umum. Salah satu sektor usaha yang sedang berkembang di Indonesia adalah industri farmasi. Kata Farmasi berasal dari kata Pharmacon yang merupakan bahasa Yunani yang berarti racun atau obat. Farmasi merupakan profesi kesehatan yang meliputi kegiatan di bidang penemuan, pengembangan, produksi, pengolahan, peracikan, informasi obat dan distribusi obat. Ilmu kefarmasian belum dikenal oleh dunia pada zaman Hiprocrates atau yang lebih dikenal dengan sebutan Bapak Ilmu Kedokteran yaitu pada tahun 460 SM sampai dengan 370 SM. Industri farmasi berperan dalam memproduksi dan mendistribusikan obat untuk dapat memenuhi kebutuhan pasar dan masyarakat. Karena kesehatan menjadi hal yang utama, pengembangan industri farmasi di Indonesia masih cukup prospektif dipacu dengan adanya program Jaminan Kesehatan Nasional (JKN). Beberapa industri farmasi asing, seperti Belanda, Jerman, Korea Selatan, Cina dan India yang bermitra dengan industri farmasi nasional untuk memproduksi bahan baku maupun produk obat. Melalui kemitraan (jointventure) diharapkan dapat terjadi transfer teknologi dan mengurangi ketergantungan impor. Hal ini membuktikan bahwa industri farmasi di Indonesia terus berkembang dan menjadi bidang usaha yang menarik.

Keaktifan dan keberhasilan usaha kini menjadi sumber utama pertumbuhan dan pembangunan ekonomi. Faktor penyebab pengangguran dan kemiskinan adalah rendahnya tingkat usaha aktif atau wirausaha di Indonesia. Pertumbuhan kewirausahaan di suatu negara dipengaruhi oleh peranan universitas dalam penyelenggaraan pendidikan kewirausahaan. Pihak universitas bertanggung jawab dalam mendidik dan memberikan kemampuan wirausaha kepada para lulusannya dan memberikan motivasi untuk berani memilih berwirausaha sebagai karir mereka. Oleh karena itu, mahasiswa sebagai kaum intelektual yang diharapkan menjadi pemimpin bangsa di masa depan dan mampu membawa perubahan sudah seharusnya menjadi pelopor dalam mengembangkan semangat kewirausahaan. Untuk mengurangi angka pengangguran, cara yang bisa dilakukan yaitu membekali diri dengan pendidikan kewirausahaan, meningkatkan mutu pendidikan dan mengembangkan pelatihan keterampilan kewirausahaan. Dengan semakin banyaknya keberhasilan usaha, diharapkan dapat mengurangi jumlah pengangguran, menciptakan kemandirian bahkan menambah jumlah lapangan pekerjaan.

Salah satu faktor yang dapat mempengaruhi keberhasilan usaha farmasi adalah motivasi berwirausaha. Motivasi berwirausaha adalah sesuatu yang dapat mempengaruhi atau mendorong seseorang yang merupakan energi pada diri seseorang untuk mencapai tujuan yang diharapkan. Motivasi yang tinggi harus ada dalam diri seseorang yang ingin menjadi wirausaha yang sukses, karena dengan adanya motivasi berwirausaha yang tinggi dapat 
membentuk mental yang ada pada diri mereka untuk selalu lebih unggul dalam mengerjakan sesuatu. Adanya motivasi berwirausaha pada diri pengusaha bisnis farmasi seperti harapan untuk memperoleh keuntungan semaksimal mungkin membuat pengusaha terus berupaya untuk mencapai target, keinginan untuk berhasil memperluas usahanya dengan memiliki banyak cabang baru, atau keinginan untuk memperoleh penghargaan sebagai distributor obat terbaik dengan kualitas produk yang berkualitas di Indonesia akan mendorong pengusaha bisnis farmasi untuk sukses dalam mengelola usahanya.

Pendidikan kewirausahaan telah dipertimbangkan sebagai salah satu faktor penting. Dengan kekayaan sumber daya Indonesia yang melimpah seharusnya bisa di kelola menjadi barang yang menghasilkan produk yang bermanfaat dan mampu bersaing dengan negara lain dengan di imbangi dengan sumber daya manusianya yang sudah dibekali pengetahuan sehingga memiliki skill yang tinggi, kreatif dan inovatif. Seorang pengusaha bisnis farmasi harus mengetahui bidang usaha yang dirintis dan dalam melakukan kegiatan usahanya harus mengetahui dengan jelas bagaimana prospek bisnisnya di masa depan. Sebagai seorang yang nantinya akan disebut ahli obat, wajib untuk memperluas pengetahuannya mengenai obat. Hal ini bisa dilakukan dengan mengikuti seminar-seminar yang dilaksanakan oleh farmasi baik lembaga atau universitas.

\section{KAJIAN LITERATUR}

\subsection{Keberhasilan Usaha}

Menurut Sopan Adrianto (2019:228), Keberhasilan Usaha adalah suatu kenyataan penyesuaian antara rencana dengan proses pelaksanaannya dan hasil yang dicapai. Ada empat metode untuk mengukur Keberhasilan Usaha yaitu : 1) Kemampuan Menyesuaian Diri, 2) Produktivitas, 3) Kepuasan Kerja, 4) Kemampuan Mendapatkan Laba dan Pencarian Sumber Daya.

\subsection{Motivasi Berwirausaha}

Menurut Leonardus Saiman (2014:25), Motivasi Berwirausaha adalah keadaan dimana seseorang merasa memiliki bekal yang cukup untuk mengelola usaha dan juga telah siap mental secara total. Indikator Motivasi Berwirausaha terdiri dari : 1) Laba, 2) Kebebasan, 3) Impian Personal, 4) Kemandirian.

\subsection{Pengetahuan Kewirausahaan}

Menurut Suryana (2013:81), Pengetahuan Kewirausahaan adalah pengetahuan dasar sebagai modal yang harus dimiliki untuk berkembang dan sukses. Ada beberapa indikator Pengetahuan Kewirausahan, antara lain : 1) Pengetahuan mengenai usaha yang akan dimasuki atau dirintis, 2) Pengetahuan lingkungan usaha yang ada, 3) Pengetahuan tentang peran dan tanggung jawab, 4) Pengetahuan tentang manajemen dan organisasi bisnis.

Berikut pengujian hipotesis penelitiannya :

$\mathrm{H}_{1}$ : Diduga adanya pengaruh Motivasi Berwirausaha terhadap Keberhasilan Usaha pada Bisnis Farmasi di Kecamatan Medan Petisah. 
$\mathrm{H}_{2}$ : Diduga adanya pengaruh Pengetahuan Kewirausahaan terhadap Keberhasilan Usaha pada Bisnis Farmasi di Kecamatan Medan Petisah.

$\mathrm{H}_{3}$ : Diduga adanya pengaruh Motivasi Berwirausaha dan Pengetahuan Kewirausahaan terhadap Keputusan Pembelian pada Bisnis Farmasi di Kecamatan Medan Petisah.

Kerangka teoritis dalam penelitian ini akan menjelaskan hubungan antara masingmasing variabel yang dapat dilihat pada gambar dibawah ini :

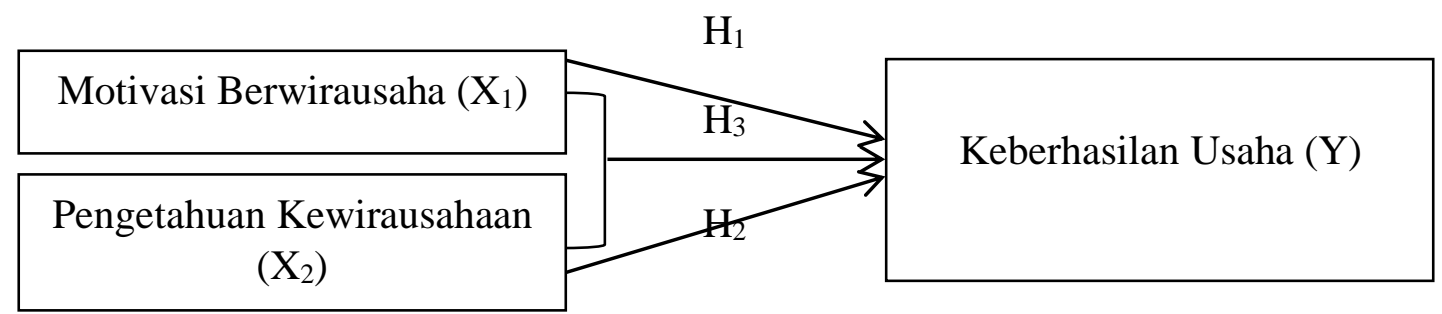

\section{Gambar 1. Kerangka Teoritis}

\section{METODOLOGI PENELITIAN}

\subsection{Jenis Data}

Jenis penelitian ini merupakan penelitian kuantitatif dimana data kuantitatif merupakan data-data yang berupa angka yang karakteristiknya selalu dalam bentuk numerik seperti data pendapatan, jumlah penduduk, tingkat konsumsi, bunga bank dan sebagainya.

\subsection{Populasi dan Sampel}

Populasi penelitian yang akan digunakan dalam penelitian adalah 40 usaha pada Bisnis Farmasi di Kecamatan Medan Petisah.

Berdasarkan data dari jumlah populasi diatas yang berjumlah 40 usaha, maka penulis menghitung ukuran sampel dengan menggunakan sampel jenuh. Sampel pada penelitian ini adalah 40 responden.

\subsection{Teknik Pengumpulan Data}

Untuk mendapatkan data yang relevan dalam penelitian maka dilakukan dengan cara wawancara yang dibantu dengan instrumen penelitian yaitu kuesioner yang diberikan kepada responden, pengamatan langsung, serta studi kepustakaan. Teknik pengumpulan data melalui kuesioner dilakukan dengan mengajukan pertanyaan kepada pihak yang berhubungan dengan masalah yang diteliti. Untuk menilai tanggapan responden maka penulis menggunakan skala Likert.

\subsection{Definisi Operasional Variabel Penelitian}

Berikut definisi operasional variabel yang akan digunakan yaitu :

Tabel 1. Definisi Operasional Variabel Penelitian

\begin{tabular}{|c|l|}
\hline Variabel & \multicolumn{1}{c|}{ Indikator } \\
\hline Variabel Dependen : & \\
\hline Keberhasilan Usaha $(\mathrm{Y})$ & 1. Produktivitas \\
\hline
\end{tabular}




\begin{tabular}{|c|c|}
\hline & $\begin{array}{l}\text { 2. Kepuasan kerja } \\
\text { 3. Kemampuan mendapatkan laba dan pencarian } \\
\text { sumber daya }\end{array}$ \\
\hline \multicolumn{2}{|l|}{ Variabel Independen : } \\
\hline Motivasi Berwirausaha $\left(\mathrm{X}_{1}\right)$ & $\begin{array}{l}\text { 1. Laba } \\
\text { 2. Kebebasan } \\
\text { 3. Impian Personak } \\
\text { 4. Kemandirian }\end{array}$ \\
\hline $\begin{array}{l}\text { Pengetahuan Kewirausahaan } \\
\qquad\left(\mathrm{X}_{2}\right)\end{array}$ & $\begin{array}{l}\text { 1. Pengetahuan mengenai usaha yang akan dirintis } \\
\text { 2. Pengetahuan lingkungan usaha yang ada } \\
\text { 3. Pengetahuan tentang peran dan tanggung jawab } \\
\text { 4. Pengetahuan tentang manejemen dan organisasi } \\
\text { bisnis }\end{array}$ \\
\hline
\end{tabular}

\subsection{Teknik Analisis Data}

Model analisis data yang digunakan dalam penelitian kali ini adalah model analisis regresi berganda. Peneliti menggunakan regresi linear berganda karena model ini berguna untuk mencari pengaruh antara dua atau lebih variabel bebas terhasap variabel terikat yang ada. Model persamaan regresi berganda adalah :

$Y=a+b_{1} X_{1}+b_{2} X_{2}+e$

Keterangan:

$\mathrm{Y} \quad=$ Keberhasilan Usaha

a $\quad=$ Konstanta

$\mathrm{b}_{1-2} \quad=$ Koefisien regresi variabel independen

$\mathrm{X}_{1} \quad=$ Variabel Motivasi Berwirausaha

$\mathrm{X}_{2} \quad=$ Variabel Pengetahuan Kewirausahaan

$\mathrm{e} \quad=$ Standard Error

\section{HASIL DAN PEMBAHASAN}

\subsection{Karakteristik Responden}

Deskripsi responden merupakan deskripsi tentang unit analisis/observasi yang diteliti yang mencakup karakteristik atau profil reponden yang diperoleh dari hasil pengolahan data kuesioner. Hasil pengumpulan data yang dilakukan pada 40 usaha bisnis farmasi yang dijadikan sebagai responden diperoleh karakteristik responden berdasarkan usia usaha dengan dominan responden $>15$ tahun.

\subsection{Uji Validitas dan Uji Reliabilitas}

Hasil uji Validitas dan Reliabilitas akan disajikan pada tabel 2 dan tabel 3 sebagai berikut ini :

Tabel 2. Hasil Uji Validitas

\begin{tabular}{|c|l|c|}
\hline Variabel & \multicolumn{1}{|c|}{ Pernyataan } & $\mathbf{r}_{\text {hitung }}$ \\
\hline \multirow{4}{*}{ Motivasi Berwirausaha $\left(\mathrm{X}_{1}\right)$} & Pernyataan -1 & 0,803 \\
\cline { 2 - 3 } & Pernyataan -2 & 0,739 \\
\cline { 2 - 3 } & Pernyataan -3 & 0,766 \\
\hline
\end{tabular}




\begin{tabular}{|c|c|c|}
\hline & Pernyataan -4 & 0,718 \\
\hline & Pernyataan -5 & 0,702 \\
\hline & Pernyataan -6 & 0,759 \\
\hline & Pernyataan -7 & 0,813 \\
\hline & Pernyataan -8 & 0,819 \\
\hline \multirow{8}{*}{ Pengetahuan Kewirausahaan $\left(\mathrm{X}_{2}\right)$} & Pernyataan - 1 & 0,855 \\
\hline & Pernyataan -2 & 0,749 \\
\hline & Pernyataan -3 & 0,615 \\
\hline & Pernyataan -4 & 0,762 \\
\hline & Pernyataan -5 & 0,686 \\
\hline & Pernyataan -6 & 0,813 \\
\hline & Pernyataan -7 & 0,751 \\
\hline & Pernyataan -8 & 0,735 \\
\hline \multirow{6}{*}{ Keberhasilan Usaha (Y) } & Pernyataan -1 & 0,780 \\
\hline & Pernyataan -2 & 0,634 \\
\hline & Pernyataan -3 & 0,853 \\
\hline & Pernyataan -4 & 0,722 \\
\hline & Pernyataan -5 & 0,743 \\
\hline & Pernyataan -6 & 0,683 \\
\hline
\end{tabular}

Sumber : Hasil Penelitian, 2020 (Data Diolah)

Dari hasil Tabel 2 diperoleh nilai $\mathrm{r}_{\text {hitung }}$ dari masing-masing item pernyataan untuk setiap variabel yang diperoleh berada diatas $t_{\text {tabel }}(0,361)$ sehingga dapat dikatakan pernyataan yang digunakan dikatakan validitas.

Tabel 3. Hasil Uji Reliabilitas

\begin{tabular}{|c|c|c|}
\hline Variabel & Jumlah Item & Cronbach's Alpha \\
\hline Motivasi Berwirausaha $\left(\mathrm{X}_{1}\right)$ & 8 & 0,893 \\
\hline Pengetahuan Kewirausahaan $\left(\mathrm{X}_{2}\right)$ & 8 & 0,871 \\
\hline Keberhasilan Usaha $(\mathrm{Y})$ & 6 & 0,818 \\
\hline
\end{tabular}

Sumber : Hasil Penelitian, 2020 (Data Diolah)

Berdasarkan Tabel 3 yang diperoleh dari masing-masing variabel terlihat Cronbach's alpha berada diatas 0,6 sehingga seluruh pernyataan dari setiap variabel dinyatakan reliabel. 


\subsection{Uji Asumsi Klasik}

\section{A. Uji Normalitas}

Uji normalitas bertujuan untuk menguji apakah dalam model regresi variabel pengganggu atau residual memiliki distribusi normal. Ada dua cara untuk mendeteksi apakah residual berdistribusi normal atau tidak, yaitu dengan analisis grafik dan uji statistik.

\section{Histogram}

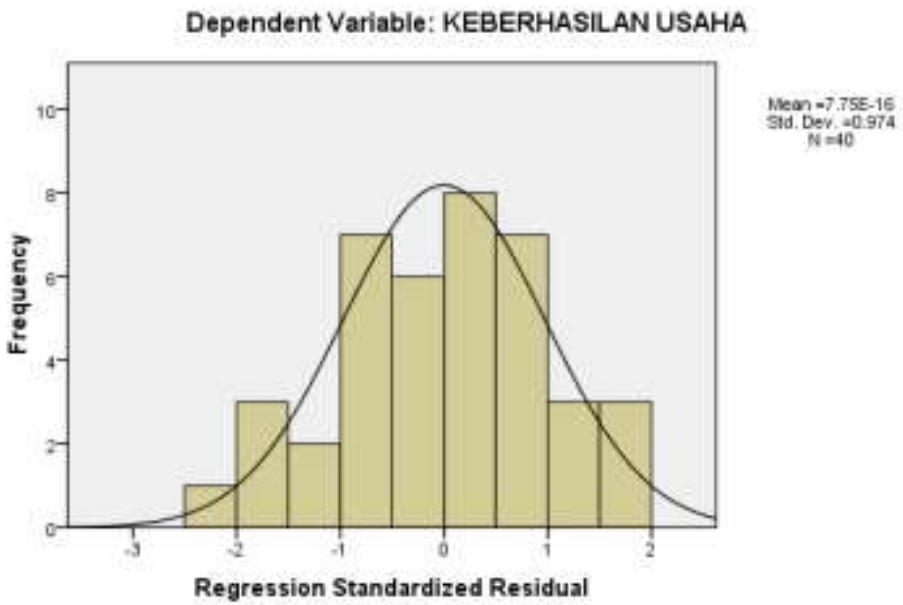

Gambar 2. Grafik Histogram

Berdasarkan Gambar 2 diatas dapat dilihat bahwa data menyebar disekitar garis diagonal dan mengikuti arah garis diagonal atau grafik histogramnya menunjukkan pola distribusi normal, maka regresi dianggap memenuhi asumsi normalitas.

Normal P-P Plot of Regression Standardized Residual

Dependent Variable: KEBERHASILAN USAHA

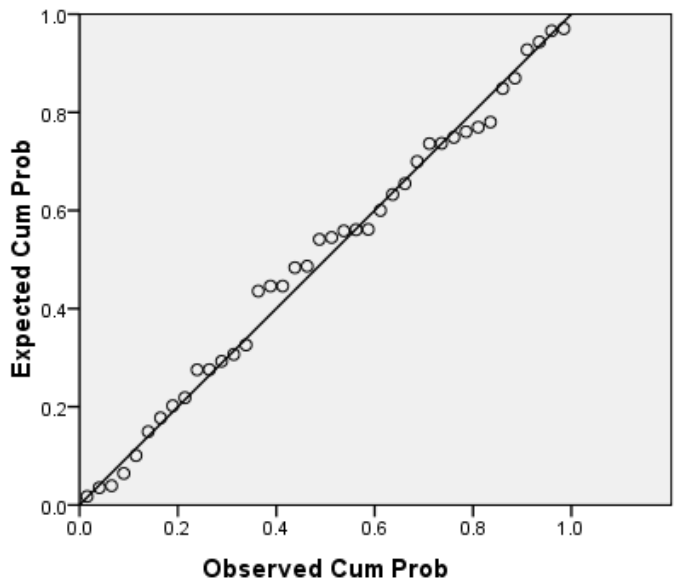

Gambar 3. Grafik Normal Probability Plot 
Berdasarkan Gambar 3 diatas dapat dilihat bahwa titik-titik mendekati garis diagonal. Hal ini menunjukkan bahwa data berdistribusi normal dan memenuhi asumsi pengujian normalitas.

Tabel 4. Uji Kolgomorov-Smirnov

One-Sample Kolmogorov-Smirnov Test

\begin{tabular}{|ll|r|}
\hline & & \multicolumn{1}{|c|}{ Unstandardized Residual } \\
\hline Normal Parameters ${ }^{\mathrm{a}, \mathrm{b}}$ & & 40 \\
& Mean & .0000000 \\
Most Extreme Differences & Std. Deviation & 1.38062498 \\
& Absolute & .084 \\
& Positive & .064 \\
& Negative & -.084 \\
Kolmogorov-Smirnov Z & & .532 \\
Asymp. Sig. (2-tailed) & & .940 \\
\hline
\end{tabular}

a. Test distribution is Normal.

b. Calculated from data.

Berdasarkan Tabel 4 di atas, dapat dilihat bahwa hasil pengujian normalitas Kolmogorov-smirnov membuktikan bahwa nilai tingkat signifikan yang dihasilkan lebih besar dari 0,05 yaitu sebesar 0,940 maka dapat disimpulkan bahwa pengujian statistik normalitas tergolong berdistribusi normal.

\section{B. Uji Multikolinieritas}

Hasil untuk pengujian multikolinieritas dapat dilihat pada tabel sebagai berikut ini :

Tabel 5. Uji Multikolinieritas Coefficients $^{\mathrm{a}}$

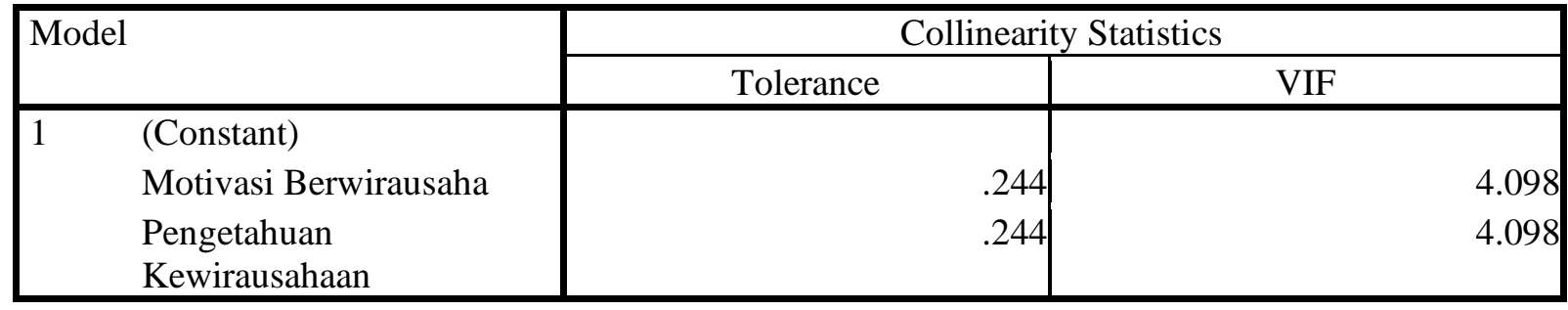

a. Dependent Variabel : Keberhasilan Usaha

Sumber : Hasil Penelitian, 2020 (Data Diolah)

Berdasarkan Tabel 5 diatas dapat dilihat bahwa nilai korelasi untuk variabel Motivasi Berwirausaha dan Pengetahuan Kewirausahaan mempunyai nilai tolerance $(0,244)>0,10$ dan nilai VIF $(4,098)<10$ sehingga dapat disimpulkan bahwa variabel Motivasi Berwirausaha dan Pengetahuan Kewirausahaan tidak terdapat adanya gejala multikolinieritas.

\section{Uji Heteroskedastisitas}

Hasil pengujian menggunakan metode grafik scatterplot dapat dilihat pada gambar dibawah ini : 


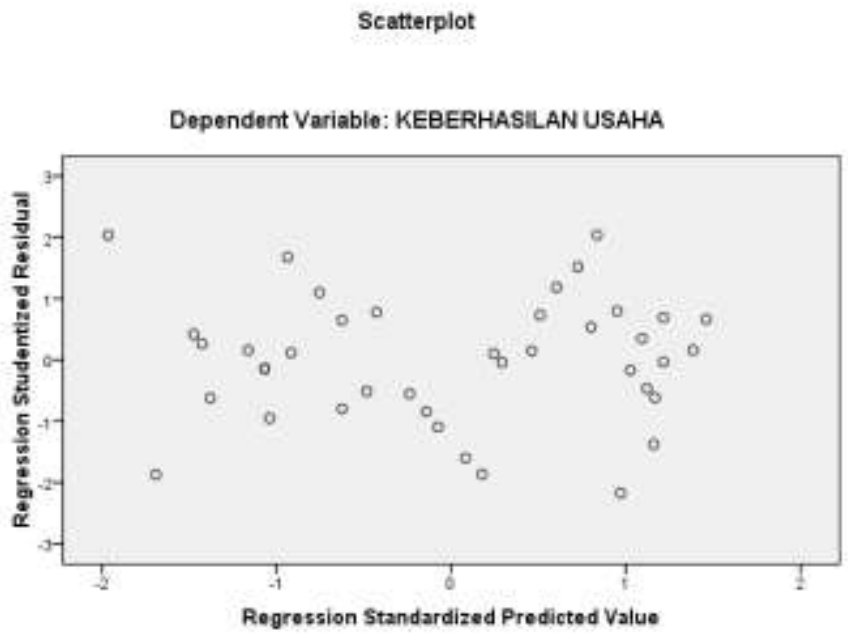

Gambar 4. Grafik Scatterplot

Berdasarkan Gambar 4 diatas, dapat dilihat bahwa titik-titik grafik Scatterplot menyebar secara acak (random) serta tersebar di atas maupun dibawah angka 0 pada sumbu Y tanpa membentuk suatu pola tertentu. Hal ini dapat disimpulkan bahwa tidak terjadi heteroskedastisitas.

\subsection{Hasil Analisis Regresi Linier Berganda}

Hasil untuk pengujian analisis regresi linier berganda dapat dilihat pada tabel sebagai berikut ini :

Tabel 6. Hasil Uji Analisis Regresi Linier Berganda

Coefficients $^{\mathrm{a}}$

\begin{tabular}{|ll|r|r|}
\hline \multirow{2}{*}{ Model } & \multicolumn{2}{|c|}{ Unstandardized Coefficients } \\
\cline { 2 - 4 } & (Constant) & \multicolumn{2}{|c|}{ Std. Error } \\
\hline 1 & \multicolumn{2}{|c|}{ B } & 1.196 \\
& Motivasi Berwirausaha & .205 & .069 \\
& Pengetahuan Kewirausahaan & .528 & .079 \\
\hline
\end{tabular}

Dependent Variabel : Keberhasilan Usaha

Sumber : Hasil Penelitian, 2020 (Data Diolah)

Berdasarkan Tabel 6 diatas, diperoleh persamaan regresi linier berganda yaitu dengan rumus berikut : Keberhasilan Usaha $=0,124+0,205$ Motivasi Berwirausaha $+0,528$ Pengetahuan Kewirausahaan + e dimana jika nilai variabel bebas $\left(\mathrm{X}_{1}\right)$ yaitu Motivasi Berwirausaha dan variabel $\left(\mathrm{X}_{2}\right)$ yaitu Pengetahuan Kewirausahaan bernilai 0 maka Keberhasilan Usaha adalah tetap sebesar 0,124. Setiap peningkatan aspek Motivasi Berwirausaha $\left(\mathrm{X}_{1}\right)$ sebesar 1 satuan, maka Keberhasilan Usaha akan meningkat sebesar 0,205. Setiap peningkatan aspek Pengetahuan Kewirausahaan $\left(X_{2}\right)$ sebesar 1 satuan, maka Keberhasilan Usaha akan meningkat sebesar 0,528.

\subsection{Hasil Pengujian Hipotesis}

\section{A. Pengujian Parsial (Uji-t)}


Hasil pengujian hipotesis secara parsial (Uji-t) dapat dilihat pada tabel dibawah ini sebagai berikut :

Tabel 7. Uji Parsial

Coefficients $^{\mathbf{a}}$

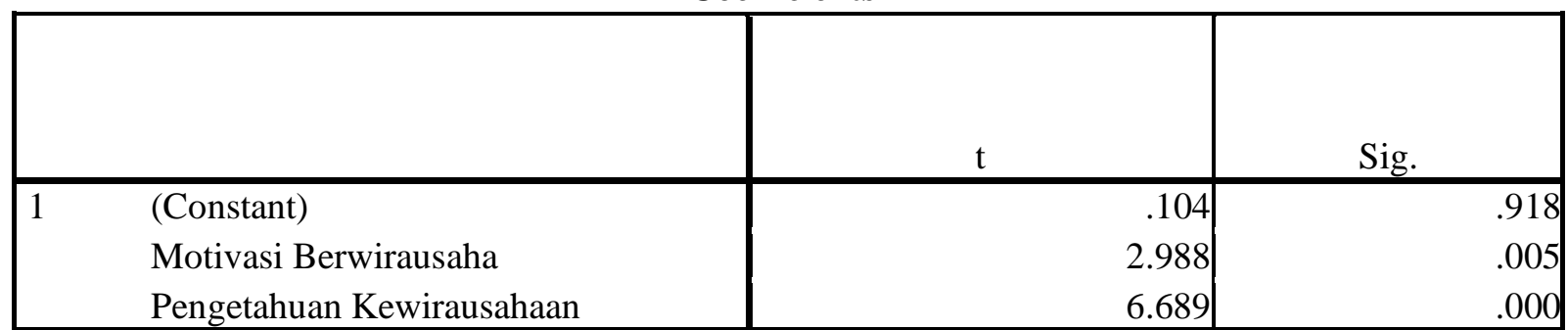

a. Dependent Variable : Keberhasilan Usaha

Sumber : Hasil Penelitian, 2020 (Data Diolah)

Variabel Motivasi Berwirausaha $\left(\mathrm{X}_{1}\right)$ memiliki nilai $\mathrm{t}_{\text {hitung }}(2,988)>\mathrm{t}_{\text {tabel }}(2,026)$ dengan tingkat signifikan $0,005<0,05$ dan Variabel Pengetahuan Kewirausahaan $\left(\mathrm{X}_{2}\right)$ memiliki nilai $t_{\text {hitung }}(6,689)>t_{\text {tabel }}(2,026)$ dengan tingkat signifikan $0,000<0,05$ sehingga dapat disimpulkan bahwa terdapat pengaruh positif yang signifikan secara parsial antara Motivasi Berwirausaha dan Pengetahuan Kewirausahaan terhadap Keberhasilan Usaha pada Bisnis Farmasi di Kecamatan Medan Petisah.

\section{B. Uji Serempak (Uji-F)}

Hasil pengujian hipotesis secara simultan (Uji-F) dapat dilihat pada tabel dibawah ini sebagai berikut :

Tabel 8. Uji Simultan

ANOVA $^{b}$

\begin{tabular}{|ll|r|r|r|r|r|}
\hline Model & & \multicolumn{1}{|c|}{ Sum of Squares } & \multicolumn{1}{c|}{ df } & Mean Square & F & Sig. \\
\hline 1 & Regression & 728.061 & 2 & 364.031 & 181.186 & $.000^{2}$ \\
& Residual & 74.339 & 37 & 2.009 & & \\
& Total & 802.400 & 39 & & & \\
\hline
\end{tabular}

a. Predictors: (Constant), Pengetahuan Kewirausahaan, Motivasi Berwirausaha

b. Dependent Variable : Keberhasilan Usaha

Sumber : Hasil Penelitian, 2020 (Data Diolah)

Berdasarkan Tabel 8 dapat dilihat nilai $F_{\text {hitung }}(181,186)>F_{\text {tabel }}(3,25)$ dengan signifikansi $0,000<0,05$ sehingga disimpulkan terdapat pengaruh yang signifikan dan positif antara Motivasi Berwirausaha dan Pengetahuan Kewirausahaan secara simultan terhadap Keberhasilan Usaha pada Bisnis Farmasi di Kecamatan Medan Petisah Medan.

\section{Koefisien Determinasi $\left(\mathbf{R}^{2}\right)$}

Hasil pengujian koefisien determinasi $\left(\mathrm{R}^{2}\right)$ dapat dilihat pada tabel dibawah ini sebagai berikut :

Tabel 9. Uji Koefisien Determinasi

Model Summary ${ }^{b}$

\begin{tabular}{|r|r|r|r|r|}
\hline Model & \multicolumn{1}{|c|}{ R } & \multicolumn{1}{|c|}{ R Square } & Adjusted R Square & Std. Error of the Estimate \\
\hline 1 & $.953^{2}$ & .907 & .902 & 1.417 \\
\hline
\end{tabular}


a. Predictors: (Constant), Pengetahuan Kewirausahaan, Motivasi Berwirausaha

b. Dependent Variable: Keberhasilan Usaha

Sumber : Hasil Penelitian, 2020 (Data Diolah)

Berdasarkan Tabel 9 diatas, dapat dilihat Nilai $R$ Square $\left(\mathrm{R}^{2}\right)$ atau koefisien determinasi yang diperoleh sebesar 0,907 artinya variabel Keberhasilan Usaha dapat dijelaskan oleh variabel Motivasi Berwirausaha dan Pengetahuan Kewirausahaan sebesar 90,7\% sedangkan sisanya 9,3\% dipengaruhi oleh faktor-faktor lain yang berasal dari luar model penelitian ini seperti kemampuan usaha dan karakteristik kewirausahaan.

\subsection{Pembahasan Hasil Penelitian}

\section{A. Pengaruh Motivasi Berwirausaha Terhadap Keberhasilan Usaha}

Berdasarkan hasil pengujian hipotesis secara parsial dengan menggunakan uji-t, diketahui bahwa variabel Motivasi Berwirausaha berpengaruh positif dan signifikan terhadap Keberhasilan Usaha Bisnis Farmasi di Kecamatan Medan Petisah.

Hasil penelitian ini sejalan dengan Dwi Gemina, Endang Silaningsih dan Erni Yuningsih (2016) dengan judul penelitian "Pengaruh Motivasi Usaha terhadap Keberhasilan Usaha Dengan Kemampuan Usaha Sebagai Variabel Mediasi pada Industri Kecil Menengah Makanan Ringan Priangan Timur-Indonesia" yang membuktikan bahwa secara parsial, Motivasi Berwirausaha berpengaruh positif dan signifikan terhadap Keberhasilan Usaha.

\section{B. Pengaruh Pengetahuan Kewirausahaan Terhadap Keberhasilan Usaha}

Berdasarkan hasil pengujian hipotesis secara parsial dengan menggunakan uji-t, diketahui bahwa variabel Pengetahuan Kewirausahaan berpengaruh positif dan signifikan terhadap Keberhasilan UsahaBisnis Farmasi di Kecamatan Medan Petisah.

Hasil penelitian ini sejalan dengan Diana Suksesiwaty Lubis, S.E., M.M. dan Dina Oktavia, S.Sos, M.I.Kom (2018) dengan judul penelitian "Pengaruh Pengetahuan Kewirausahaan dan Karakteristik Kewirausahaan Terhadap Keberhasilan Usaha pada Wirausaha Mikro di Kelurahan Madras Hulu Medan Polonia" yang membuktikan bahwa secara parsial, Pengetahuan Kewirausahaan berpengaruh positif dan signifikan terhadap Keberhasilan Usaha.

\section{Pengaruh Motivasi Berwirausaha Dan Pengetahuan Kewirausahaan Terhadap Keberhasilan Usaha}

Berdasarkan hasil pengujian hipotesis secara simultan dengan menggunakan uji-F, diketahui bahwa variabel Motivasi Berwirausaha dan Pengetahuan Kewirausahaan berpengaruh positif dan signifikan terhadap Keberhasilan UsahaBisnis Farmasi di Kecamatan Medan Petisah.

Hasil penelitian ini sejalan dengan Dwi Gemina, Endang Silaningsih dan Erni Yuningsih (2016) dengan judul penelitian "Pengaruh Motivasi Usaha terhadap Keberhasilan Usaha Dengan Kemampuan Usaha Sebagai Variabel Mediasi pada Industri Kecil Menengah Makanan Ringan Priangan Timur-Indonesia" yang membuktikan bahwa secara simultan, Motivasi Usaha berpengaruh positif dan signifikan terhadap Keberhasilan Usaha. 
Hasil penelitian ini sejalan dengan Diana Suksesiwaty Lubis, S.E., M.M. dan Dina Oktavia, S.Sos, M.I.Kom (2018) dengan judul penelitian "Pengaruh Pengetahuan Kewirausahaan dan Karakteristik Kewirausahaan Terhadap Keberhasilan Usaha pada Wirausaha Mikro di Kelurahan Madras Hulu Medan Polonia" yang membuktikan bahwa secara simultan, Pengetahuan Kewirausahaan berpengaruh positif dan signifikan terhadap Keberhasilan Usaha.

\section{SIMPULAN DAN REKOMENDASI}

\subsection{Kesimpulan}

Berdasarkan hasil dan pembahasan penelitian, maka penulis membuat beberapa kesimpulan sebagai berikut ini :

1. Hasil penelitian ini menyatakan pengaruh Motivasi Berwirausaha dan Pengetahuan Kewirausahaan terhadap Keberhasilan Usaha yang ditunjukkan dari hasil analisis regresi linear berganda memberikan arti bahwa setiap peningkatan aspek pada variabel Motivasi Berwirausaha dan Pengetahuan Kewirausahaan sebesar satu-satuan, maka Keberhasilan Usaha akan meningkat.

2. Motivasi Berwirausaha secara parsial memiliki pengaruh positif dan signifikan terhadap Keberhasilan Usaha pada Bisnis Farmasi di Kecamatan Medan Petisah.

3. Pengetahuan Kewirausahaan secara parsial memiliki pengaruh positif dan signifikan terhadap Keberhasilan Usaha pada Bisnis Farmasi di Kecamatan Medan Petisah.

4. Motivasi Berwirausaha dan Pengetahuan Kewirausahaan secara simultan memiliki pengaruh positif dan signifikan terhadap Keberhasilan Usaha pada Bisnis Farmasi di Kecamatan Medan Petisah.

5. Motivasi Berwirausaha dan Pengetahuan Kewirausahaan dapat menjelaskan keterkaitannya dengan Keberhasilan Usaha pada Bisnis Farmasi di Kecamatan Medan Petisah.

\subsection{Implikasi Manajerial}

Berdasarkan analisa yang telah penulis lakukan, maka didapatkan hasil implikasi yang dapat diberikan kepada perusahaan sebagai berikut :

1. Motivasi Berwirausaha pada Usaha Bisnis Farmasi di Kecamatan Medan Petisah perlu diperhatikan, karena:

a. Seorang wirausaha mempunyai visi dan misi dari usaha yang ia jalankan. Jika visi dan misi yang diberikan jelas, maka akan selalu memacu seorang wirausaha untuk menjalankan usaha dengan lebih baik.

b. Harus mempunyai semangat yang tinggi untuk memajukan usahanya seperti semangat dalam mengasah kreativitas, berinovasi dan memberikan terobosan yang terbaik.

2. Usaha Bisnis Farmasi di Kecamatan Medan Petisah harus mempertahankan Pengetahuan Kewirausahaan dalam peningkatan Keberhasilan Usaha, dimana:

a. Memahami produk yang banyak diminati oleh konsumen, selalu menawarkan beberapa variasi produk dengan kualitas baik agar konsumen merasa puas dengan produk yang dibeli. 
b. Konsisten memperluas wawasan dan memahami bidang usaha yang akan dijalankan.

\subsection{Saran Akademis}

Saran-saran yang dapat diberikan kepada akademis adalah :

1. Menambah Variabel Penelitian

Bagi peneliti selanjutnya yang ingin meneliti atau melanjutkan penelitian ini, disarankan untuk dapat meneruskan penelitian ini dengan mencari variabel lain yang mempengaruhi Keberhasilan Usaha.

2. Menambah jumlah responden.

Untuk penelitian selanjutnya diharapkan peneliti dapat meningkatkan jumlah responden dengan pemilihan wilayah cakupan yang lebih luas sehingga lebih dapat mewakili keadaan yang sebenarnya.

3. Perluasan Cakupan Geografis.

Salah satu keterbatasan dalam penelitian ini adalah responden yang kurang beragam karena sampel hanya diambil dari satu tempat saja yaitu Bisnis Farmasi di Kecamatan Medan Petisah. Selanjutnya diharapkan penelitian berikutnya mampu memperluas cakupan wilayahnya. Contohnya penelitian di beberapa kecamatan di Kota Medan.

\section{DAFTAR PUSTAKA}

Adrianto, Sopan. 2019. PENEROKA Kepemimpinan Sekolah. Jakarta : PT. Elex Media Komputindo.

Arikunto, Suharsimi. 2010. Prosedur Penelitian Suatu Pendekatan Praktik. Jakarta: Rineka Cipta.

Armayanti, Nelly. dkk. 2019. Dasar-dasar Kewirausahaan. Medan : Yayasan Kita Menulis.

Benedicta Prihatin Dwi, Riyanti. 2003. Kewirausahaan Dari Sudut Pandang Psikologi Kepribadian. Jakarta : Grasindo.

Dharmawati, D. Made. 2016. Kewirausahaan. Depok : PT. Raja Grafindo Persada.

Diana Suksesiwaty Lubis, S.E., M.M. dan Dina Oktavia, S.Sos, M.I.Kom. 2018. "Pengaruh Pengetahuan Kewirausahaan dan Karakteristik Kewirausahaan Terhadap Keberhasilan Usaha pada Wirausaha Mikro di Kelurahan Madras Hulu Medan Polonia”. Jurnal Stindo Profesional. Vol. IV No. 4. Tahun 2018.

Doddy Astya Budy. 2017. "Pengaruh Pendidikan Kewirausahaan dan Motivasi Kewirausahaan Terhadap Keterampilan Berwirausaha Mahasiswa Universitas 17 Agustus 1945 Jakarta”. Journal for Business and Entrepreneur. Vol. 1 No. 1. Tahun 2017.

Dwi Gemina, Endang Silaningsih, dan Erni Yuningsih. 2016. "Pengaruh Motivasi Usaha terhadap Keberhasilan Usaha dengan Kemampuan Usaha sebagai Variabel Mediasi Pada Industri Menengah Makanan Ringan Priangan Indonesia”. Jurnal Manajemen Teknologi. Universitas Djuanda Bogor. Bogor.

Echdar, Saban. 2013. Manajemen Entrepreneurship. Yogyakarta : ANDI.

Ghozali, Imam. 2013. “Aplikasi Analisis Multivariate Dengan Program IBM SPSS 23”. Semarang : Badan Penerbit Universitas Diponegoro. 
Hendrawan, Josia Sanchaya dan Hani Sirine. 2017. "Pengaruh Sikap Mandiri, Motivasi dan Pengetahuan Kewirausahaan terhadap Minat Berwirausaha”. Asian Journal of Innovation and Entrepreneurship Vol. 02, No. 03. Tahun 2017.

Hendro. 2011. Dasar-Dasar Kewirausahaan. Jakarta : Erlangga.

Nur Azizah, Siti. 2013. "Pengaruh Motivasi Usaha dan Kemampuan Usaha Dalam

Meningkatkan Keberhasilan Usaha Pada Usah Mikro Pedagang Sate di Desa Candiwulan Kecamatan Adimulyo Kebumen". Jurnal Fokus Bisnis. STIE Putra Bangsa. Kebumen

Marina, Anna. dkk. 2018. Pengantar Bisnis. Jakarta : Prenadamedia Group.

Primiana, Ina. 2009. Menggerakkan Sektor Riil UKM \& Industri. Bandung : Alfabeta.

Purnama, Chamdan dan Suyanto. 2010. "Motivasi dan Kemampuan Usaha Dalam Meningkatkan Keberhasilan Usaha Industri Kecil (Studi Pada Industri Kecil Sepatu di Jawa Timur)". Jurnal Manajemen dan Kewirausahaan, Vol 12 No 2. Tahun 2010.

Saiman, Leonardus. 2014. Kewirausahaan. Jakarta : Salemba Empat

Sugiyono. 2015. Metode Penelitian Kuantitatif, Kualitatif dan R\&D. Bandung : Afabeta.

Suryana. 2013. Kewirausahaan. Jakarta: Salemba Empat.

Suryanto, Bambang dan Daryanto. 2019. Pengantar Manajemen Bisnis. Yogyakarta : Gaya Media.

Trisnawati, Novi. 2014. "Pengaruh Pengetahuan Kewirausahaan dan Dukungan Sosial Keluarga Pada Minat Berwirausaha Siswa SMK Negeri 1 Pamekasan”. Jurnal Ekonomi Pendidikan dan Kewirausahaan. Universitas Negeri Surabaya. Surabaya 